\title{
Can ultrasound predict labour outcome in operative vaginal deliveries?
}

PhD kandidat Birgitte Heiberg Kahrs ${ }^{1,2}$

${ }^{1}$ Nasjonalt senter for fostermedisin, St. Olavs Hospital

2 Institutt for klinisk og molekylær medisin, Fakultet for medisin og helsevitenskap, NTNU

\section{Langsom fremgang i trykketiden i en fødsel} er en dagligdags hendelse på fødeavdelingen. Hvis ikke barnet blir født spontant, kan man enten hjelpe til med en operativ vaginal forløsning eller man kan gjøre keisersnitt. For å vite hva man skal gjøre i en slik situasjon, må man vurdere fosterhodets nivå i bekkenet og fosterhodets innstiling. Dette har man tradisjonelt sett gjort med en vaginalundersøkelse. I min PhD har jeg undersøkt nytteverdien av ultralydmålinger i denne fasen av fødselen.

Tidligere studier har vist at ultralyd har potensial til å bedre presisjonene av vurderingen av fosterhodets nivå og innstilling i bekkenet sammenlignet med den tradisjonelle vaginalundersøkelsen. Målet med studien vår var å vurdere om ultralydmålinger kunne predikere varigheten av vakuumforløsningen, forløsningsmetode og neonatalt utfall hos førstegangsfødende med langsom fremgang i trykketiden. Vi ønsket også å undersøke om fosterhodet roterte spontant under vakuumforløsningen og om fosterhodets innstiling i bekkenet hadde innflytelse på varigheten av vakuumforløsningen, forløsningsmetode og neonatalt utfall. Til slutt ønsket vi å vurdere om fosterhodets bevegelse i fødselskanalen under aktiv trykking vurdert med transperineal ultralyd, var assosiert med varigheten av vakuumforløsningen, forløsningsmetode og neonatalt utfall.

Vi utførte en prospektiv kohortstudie i perioden november 2013 til juli 2016. Syv fødeavdelinger i Europa deltok: Stavanger universitetssykehus, St. Olavs hospital i Trondheim, Queen Charlotte's and Chelsea
Hospital (Imperial College Healthcare NHS Trust, Storbritannia), Lund Universitetssykehus (Sverige), Hvidovre Universitetssykehus (Danmark), University Hospital of Bologna (Italia) og University Hospital of Parma (Italia). Kvinnene ble inkludert i studien når langsom fremgang i trykketiden ble diagnostisert, de hadde trykket aktivt i 45 minutter og vakuumforløsning ble vurdert. Det var normal fosterlyd hos alle og forløsningen ble vurdert på indikasjon langsom fremgang i trykketiden. Transabdominal og transperineal ultralyd ble utført for å vurdere fosterhodets innstilling og nivå i bekkenet. Ved den transperineale ultralyden ble head-perineum distance (HPD) målt ( $\triangleright$ Fig. 1). HPD er en transverse transperineal ultralyd hvor ultralydproben blir trykket mot perineum til man møter motstand og den korteste avstanden mellom ultralydproben og fosterhodet blir målt. Fødselshjelperen som var ansvarlig for kvinnen gjorde den samme vurderingen ved hjelp av en vaginalundersøkelse. Ultralydundersøkeren og fødselshjelperen var blindet for hverandres vurderinger.

Til sammen ble 222 kvinner inkludert. Varigheten av vakuumforløsningen var kortere hos kvinner med HPD $\leq 25$ mm. Fosterhodets nivå i bekkenet målt som HPD kunne predikere forløsningsmetode, og sammen med vurderingen av fosterhodets innstilling økte nøyaktigheten ytterligere. Hvis HPD $\leq 35 \mathrm{~mm}$, og fosterhodets innstilling i bekkenet var occiput anterior, var sjansen for en vellykket vaginal forløsning $98 \%$. Selv om alle kvinnene som ble inkludert i studien hadde normal fosterlyd, var det flere nyfødte med $\mathrm{pH}$ i navlesnor på < 7.10 i gruppen som ble forløst med en med HPD $\leq 35$ mm.

Når vi undersøkte om fosterhodet roterte under vakuumforløsning, fant vi at rotasjon fra occiput transvers innstilling til occiput anterior innstilling skjedde i $74 \%$ av tilfellene, og i fra occiput posterior til occiput anterion innstilling i $60 \%$ av tilfellene. Det var flere til-

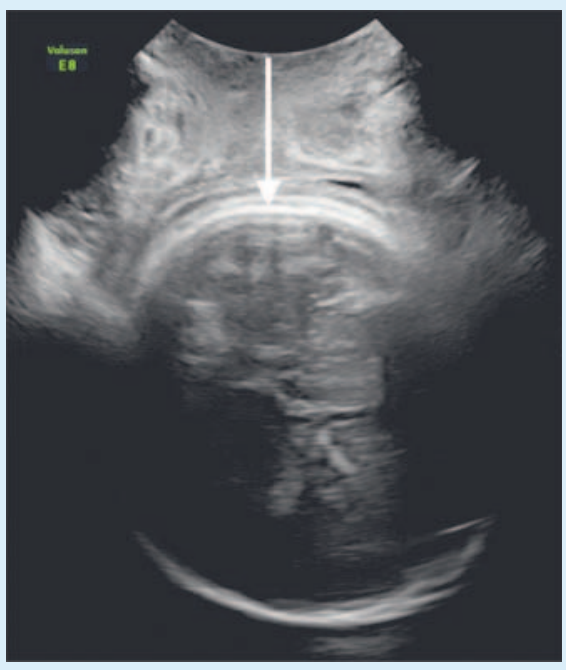

- Fig. 1 Transperinal ultralydmåling av head-perineum distance (HPD).

feller hvor man måtte endre forløsningsmetode fra vakuumforløsning til tangforløsning eller keisersnitt hvis fosterhodet ikke lå i en occiput anterior (23\%) enn hvis det lå i en occiput anterior (10\%). Varigheten av vakuumforløsningen var kortere hvis fosterhodet var i en occiput anterior innstilling. Det var ingen forskjeller i utfall hos de nyfødte.

Bevegelsen av fosterhodet i fødselskanalen ble angitt som differansen mellom HPD målt mellom riene og under trykking på ri. Hvis fosterhodet ikke beveget seg eller det var en minimal bevegelse, varte vakuumforløsningen lengre og det var en høyere risiko for keisersnitt. Det var heller ikke her forskjell i neonatalt utfall.

Hovedkonklusjonen i min avhandling er at ultralydmålinger gjort rett før vakuumforløsning er assosiert med varighet av vakuumforløsning og forløsningsmetode, og i tillegg er fosterhodets nivå, målt med HPD, assosiert med navlesnors $\mathrm{pH}$. Ultralydundersøkelsen har potensialet til å trygge fødselshjelperen til å utføre sikre vakuumforløsninger. 